\title{
Front Matter: Volume 6630
}

, "Front Matter: Volume 6630," Proc. SPIE 6630, Confocal, Multiphoton, and Nonlinear Microscopic Imaging III, 663001 (14 August 2007); doi: $10.1117 / 12.753881$

SPIE. Event: European Conferences on Biomedical Optics, 2007, Munich, Germany 


\title{
PROGRESS IN BIOMEDICAL OPTICS AND IMAGING
}

Vol. 8, No. 43

\section{Confocal, Multiphoton, and Nonlinear Microscopic Imaging III}

\author{
Tony Wilson \\ Ammasi Periasamy \\ Editors
}

17-18 June 2007

Munich, Germany

Sponsored and Published by

SPIE

OSA-Optical Society of America

Financial Sponsor

(G.) EOARD—European Office of Aerospace Research and Development

We wish to thank the following for their contribution to the success of this conference:

European Office of Aerospace Research and Development

Air Force Office of Scientific Research

United States Air Force Research Laboratory (www.london.af.mil)

Cooperating Organizations

EOS-European Optical Society

WLT-Wissenschaftliche Gesellschaft Lasertechnik e.V. (Germany)

DGLM-Deutsche Gesellschaft für Lasermedizin e.V. (Germany) 
The papers included in this volume were part of the technical conference cited on the cover and title page. Papers were selected and subject to review by the editors and conference program committee. Some conference presentations may not be available for publication. The papers published in these proceedings reflect the work and thoughts of the authors and are published herein as submitted. The publisher is not responsible for the validity of the information or for any outcomes resulting from reliance thereon.

Please use the following format to cite material from this book:

Author(s), "Title of Paper," in Confocal, Multiphoton, and Nonlinear Microscopic Imaging III, edited by Tony Wilson, Ammasi Periasamy, Proceedings of SPIE-OSA Biomedical Optics, Vol. 6630 (SPIE, Bellingham, WA, 2007) Article CID Number.

ISSN 1605-7422

ISBN 9780819467744

\section{Copublished by}

\section{SPIE}

P.O. Box 10, Bellingham, Washington 98227-0010 USA

Telephone +1 3606763290 (Pacific Time) · Fax +1 3606471445

SPIE.org

and

OSA-Optical Society of America

2010 Massachusetts Ave., N.W.

Washington, D.C. 20036

Telephone 1 202/223-8130 (Eastern Time) · Fax 1 202/223-1096

http://www.osa.org

Copyright @ 2007, Society of Photo-Optical Instrumentation Engineers and Optical Society of America.

Copying of material in this book for internal or personal use, or for the internal or personal use of specific clients, beyond the fair use provisions granted by the U.S. Copyright Law is authorized by the publishers subject to payment of copying fees. The Transactional Reporting Service base fee for this volume is $\$ 18.00$ per article (or portion thereof), which should be paid directly to the Copyright Clearance Center (CCC), 222 Rosewood Drive, Danvers, MA 01923. Payment may also be made electronically through CCC Online at copyright.com. Other copying for republication, resale, advertising or promotion, or any form of systematic or multiple reproduction of any material in this book is prohibited except with permission in writing from the publisher. The CCC fee code is 1605-7422/07/ $\$ 18.00$.

Paper Numbering: Proceedings of SPIE-OSA Biomedical Optics follow an e-First publication model, with papers published first online and then in print and on CD-ROM. Papers are published as they are submitted and meet publication criteria. A unique, consistent, permanent citation identifier (CID) number is assigned to each article at the time of the first publication. Utilization of CIDs allows articles to be fully citable as soon they are published online, and connects the same identifier to all online, print, and electronic versions of the publication. In this six-digit CID article numbering system:

- The first four digits correspond to the volume number.

- The last two digits indicate publication order within the volume using a Base 36 numbering system employing both numerals and letters. These two-number sets start with 00, 01, 02, 03, 04, $05,06,07,08,09,0 A, 0 B \ldots$. OZ, followed by 10-1Z, 20-2Z, etc.

The CID number appears on each page of the manuscript. The complete citation is used on the first page, and an abbreviated version on subsequent pages. Numbers in the index correspond to the last two digits of the six-digit CID number. 


\section{Contents}

ix Conference Committee

\section{SESSION 1 APPLICATIONS FOR CELLULAR AND TISSUE IMAGING}

663002 Two-color intranuclear distance measurements of gene regions in human lymphocytes [6630-01]

S. Fenz, Institute for Bio- and Nanosystems, Research Ctr. Jülich (Germany) and Kirchhoff Institute for Physics, Univ. of Heidelberg (Germany); H. Mathée, G. Kreth, D. Baddeley, Y. Weiland, J. Schwarz-Finstlerle, C. G. Cremer, Kirchhoff Institute for Physics, Univ. of Heidelberg (Germany); U. J. Birk, Kirchhoff Institute for Physics, Univ. of Heidelberg (Germany) and Institute of Electronic Structure \& Laser, FORTH (Greece)

663003 In vivo imaging of anatomical features of the nematode Caenorhabditis elegans using non-linear (TPEF-SHG-THG) microscopy [6630-02]

E. J. Gualda, G. Filippidis, G. Voglis, M. Mari, C. Fotakis, N. Tavernarakis, Foundation for Research and Technology-Hellas (Greece)

663004 Functional imaging of skeletal muscle fiber in different physiological states by second harmonic generation [6630-03]

V. Nucciotti, C. Stringari, L. Sacconi, F. Vanzi, C. Tesi, N. Piroddi, C. Poggesi, Univ. of Florence (Italy); C. Castiglioni, A. Milani, Politecnico Milano (Italy); M. Linari, G. Piazzesi, V. Lombardi, F. S. Pavone, Univ. of Florence (Italy)

663005 Multiphoton imaging of rabbit cornea treated with mitomycin C after photorefractive keratectomy [6630-04]

C.-M. Hsueh, W. Lo, National Taiwan Univ. (Taiwan); T.-J. Wang, F.-R. Hu, National Taiwan Univ. Medical Collge (Taiwan) and National Taiwan Univ. Hospital (Taiwan); C.-Y. Dong, National Taiwan Univ. (Taiwan)

663006 Post conductive keratoplasty visualization of rabbit cornea by multiphoton microscopy [6630-05]

W. LO, National Taiwan Univ. (Taiwan); T.-J. Wang, F.-R. Hu, National Taiwan Univ. Medical College (Taiwan) and National Taiwan Univ. Hospital (Taiwan); C.-Y. Dong, National Taiwan Univ. (Taiwan)

663007 Enhanced fluorescence cell imaging with metal-coated slides [6630-06]

E. Le Moal, Lab. Matériaux et Phénomènes Quantiques, CNRS, Univ. Paris 7 (France), Lab. de Physique du Solide, ESPCI (France), and Lab. de Photophysique Moléculaire, CNRS (France); E. Fort, Lab. Matériaux et Phénomènes Quantiques, CNRS, Univ. Paris 7 (France), Lab. de Physique du Solide, ESPCI (France); S. Lévêque-Fort, Lab. de Photophysique Moléculaire, CNRS (France); A. Janin, H. Murata, Lab. de Pathologie, INSERM, Univ. Paris 7 (France); F. P. Cordelières, Institut Curie, CNRS (France) 
6630 OA Microscopic fluorescence lifetime and hyperspectral imaging with digital micromirror illuminator [6630-09]

A. Bednarkiewicz, Institute of Health and Customer Protection, European Commission Joint Research Ctr. (Italy) and Institute for Low Temperature and Structure Research (Poland); M. P. Whelan, Institute of Health and Customer Protection, European Commission Joint Research Ctr. (Italy)

6630 OB Development of a TIRF-FLIM microscope for biomedical applications [6630-10] P. Blandin, Lab. de Photophysique Moléculaire et Ctr. Laser, Univ. Paris Sud (France) and Institut d'Optique Graduate School, Campus Polytechnique (France); S. Lévêque-Fort, S. Lécart, Lab. de Photophysique Moléculaire et Ctr. Laser, Univ. Paris Sud (France); P. Zeller, Z. Lenkei, Lab. de Neurobiologie et Diversité Cellulaire, ESPCI (France); F. Druon, P. Georges, Institut d'Optique Graduate School, Campus Polytechnique (France)

\section{SESSION $3 \quad$ ACCURACY AND QUANTITATION IN MICROSCOPY}

6630 OC Refractive index determination by index-mismatch-induced spherical aberration [6630-1 1] P.-J. Su, P. T. FwU, V. Hovhannisyan, C.-Y. Dong, National Taiwan Univ. (Taiwan)

6630 OD Determination of the confocal volume for quantitative fluorescence correlation spectroscopy [6630-12]

S. Rüttinger, Physikalisch-Technische Bundesanstalt (Germany); V. Buschmann, B. Krämer, R. Erdmann, PicoQuant GmbH (Germany); R. Macdonald, Physikalisch-Technische Bundesanstalt (Germany); F. Koberling, PicoQuant GmbH (Germany)

6630 OE Quantitative determination of specimen properties using computational differentialinterference contrast (DIC) microscopy [6630-13]

C. Preza, Univ. of Memphis (USA); J. A. O'Sullivan, Washington Univ. in St. Louis (USA)

6630 OF Two- and one-photon color confocal screening microscope [6630-14]

C. Seebacher, Biolmaging Zentrum, LMU Munich (Germany); J. Walter, TILL I.D. GmbH (Germany); R. Uhl, Biolmaging Zentrum, LMU Munich (Germany), TILL I.D. GmbH (Germany), and TILL Photonics GmbH (Germany)

\section{SESSION 4 ADVANCED INSTRUMENTATION FOR MICROSCOPY I}

$6630 \mathrm{OH}$ Infrared multiphoton microscopy beyond 1 micron: system design and biomedical applications [6630-16] E. Büttner, APE GmbH (Germany); V. Andresen, LaVision BioTec GmbH (Germany); I. Rimke, APE GmbH (Germany); P. Friedl, Univ. of Würzburg (Germany)

6630 ol Coherent light microscopy with a multi-spot source [6630-17] R. Riesenberg, M. Kanka, J. Bergmann, Institute for Photonic Technology (Germany)

$6630 \mathrm{0J}$ Phase reconstruction by multiple plane detection for holographic microscopy [6630-18] A. Grjasnow, R. Riesenberg, A. Wuttig, Institute of Photonic Technology (Germany) 
6630 ON Spherical aberration cancellation in a polarized photon-pairs confocal laser scanning microscope [6630-22]

C.-H. Chang, National Central Univ. (Taiwan); C. Chou, National Central Univ. (Taiwan) and National Yang Ming Univ. (Taiwan); H.-F. Chang, National Central Univ. (Taiwan) and Science and Technology Institute of Northern Taiwan (Taiwan); H.-F. Yau, National Central Univ. (Taiwan); H.-J. Huang, National Yang Ming Univ. (Taiwan); W.-C. Kuo, National Taiwan Normal Univ. (Taiwan)

\section{SESSION 5 ADVANCED INSTRUMENTATION FOR MICROSCOPY II}

6630 OP Aberration-free refocusing in high numerical aperture microscopy [6630-24]

T. Wilson, E. Botcherby, R. Juškaitis, M. Booth, Univ. of Oxford (United Kingdom)

$66300 Q$ Two-photon luminescence imaging of cancerous tissue using gold nanorods as bright contrast agents [6630-25]

N. J. Durr, B. A. Holfeld, T. Larson, D. K. Smith, B. A. Korgel, The Univ. of Texas at Austin (USA); K. Sokolova, The Univ. of Texas at Austin (USA) and The Univ. of Texas M.D. Anderson

Cancer Ctr. (USA); A. Ben-Yakar, The Univ. of Texas at Austin (USA)

6630 OR A new easy to use light source for CARS microscopy based on an optical parametric oscillator [6630-26]

I. Rimke, APE GmbH (Germany); C. L. Evans, Harvard Univ. (USA); E. Büttner, APE GmbH (Germany); S. Xie, Harvard Univ. (USA)

6630 OS Multiplex coherent anti-Stokes Raman scattering microscopy on lipid droplets in HeLa cells [6630-27]

H. A. Rinia, Univ. of Amsterdam (Netherlands); K. N. J. Burger, Utrecht Univ. (Netherlands); M. Bonn, FOM Institute for Atomic and Molecular Physics (Netherlands); M. Müller, Univ. of Amsterdam (Netherlands)

6630 OT Confocal Raman microscopy for investigation of the level of differentiation in living neuroblastoma tumor cells [6630-28]

C. Scalfi-Happ, Institute for Laser Technologies in Medicine and Metrology (Germany); A. Jauss, O. Hollricher, WITec GmbH (Germany); S. Fulda, Univ. Ulm, Children's Hospital (Germany); C. Hauser, R. Steiner, A. Rück, Institute for Laser Technologies in Medicine and Metrology (Germany)

\section{SESSION 6 MICROSCOPY IN DERMATOLOGY}

6630 OU Two-photon microscopy of non-melanoma skin cancer: initial experience and diagnostic criteria ex vivo (Invited Paper) [6630-29]

M. B. Ericson, Göteborg Univ. (Sweden) and Sahlgrenska Univ. Hospital, Göteborg Univ. (Sweden); J. Paoli, Sahlgrenska Univ. Hospital, Göteborg Univ. (Sweden); C. Ljungblad, Göteborg Univ. (Sweden) and Chalmers Univ. Technology (Sweden); A. Odu, Linköping Univ. (Sweden); M. Smedh, Ctr. for Cellular Imaging, Göteborg Univ. (Sweden);

A.-M. Wennberg, Sahlgrenska Univ. Hospital, Göteborg Univ. (Sweden) 
$66300 \mathrm{~V}$ In vivo multiphoton tomography: a non invasive powerful tool for biochemical investigation of human skin [6630-30]

R. Le Harzic, JenLab GmbH (Germany) and Fraunhofer Institute of Biomedical Technology (Germany); A. Colonna, L'Oréal Recherche (France); R. Bückle, JenLab GmbH (Germany); A. Ehlers, Fraunhofer Institute of Biomedical Technology (Germany); C. Hadjur, F. Leroy, F. Flament, R. Bazin, B. Piot, L'Oréal Recherche (France); I. Riemann, K. König, Fraunhofer Institute of Biomedical Technology (Germany)

6630 OY Utilizing nonlinear optical microscopy to investigate the development of early cancer in nude mice in vivo [6630-33]

C.-C. Wang, F.-C. Li, National Taiwan Univ. (Taiwan); S.-J. Lin, National Taiwan Univ. Hospital and College of Medicine (Taiwan); W. Lo, C.-Y. Dong, National Taiwan Univ. (Taiwan)

$66300 Z$ Investigation of depilatory mechanism by use of multiphoton fluorescent microscopy [6630-34]

C.-Y. Lin, G. Lee, National Taiwan Univ. (Taiwan); S.-Y. Jee, National Taiwan Univ. Hospital and College of Medicine (Taiwan); C.-Y. Dong, National Taiwan Univ. (Taiwan); S.-J. Lin, National Taiwan Univ. (Taiwan) and Institute of Biomedical Engineering, National Taiwan Univ. (Taiwan)

663010 Multiphoton microscopy for the investigation of trans-cutaneous drug delivery [6630-35] F. Stracke, Fraunhofer Institute for Biomedical Technology (Germany); M. Schneider, B. Weiss, C.-M. Lehr, U. F. Schäfer, Saarland Univ. (Germany); K. König, Fraunhofer Institute for Biomedical Technology (Germany)

POSTER SESSION

663011 Simultaneous imaging of confocal fluorescence and raman spectrum [6630-36] M. Ahn, T. Kim, H. You, I. Song, D. Gweon, Korea Advanced Institute of Science and Technology (South Korea)

663012 Improvement of axial resolution in confocal microscopy using heterodyne illumination [6630-37]

S. Lee, H. Yoo, B. S. Chun, W. Chun, D. Gweon, Korea Advanced Institute of Science and Technology (South Korea)

663014 Intravital multiphoton microscopy for imaging hepatobiliary function [6630-39]

F.-C. Li, T.-L. Sun, National Taiwan Univ. (Taiwan); H.-S. Lee, S.-M. Yang, National Taiwan Univ. Hospital (Taiwan); C.-Y. Dong, National Taiwan Univ. (Taiwan)

663015 Multifocal multispectral descanned detection in TPLSM [6630-40]

T. Bergmann, M. Tiemann, J. Martini, K. Tönsing, D. Anselmetti, Bielefeld Univ. (Germany)

663016 Fiber laser-based light source for CARS microspectroscopy [6630-41]

E. R. Andresen, C. K. Nielsen, J. Thøgersen, S. R. Keiding, Univ. of Aarhus (Denmark)

663017 Spatially resolved fluorescence correlation spectroscopy based on electron multiplying CCD [6630-42]

M. Matsumoto, T. Sugiura, K. Minato, Nara Institute of Science and Technology (Japan) 
663018 Evaluation of a new method for the determination of experimental PSF of a wide-field microscope using white-light and a linear sensor [6630-43]

M. P. Macedo, Instituto Superior de Engenharia de Coimbra (Portugal) and Univ. Coimbra (Portugal); A. J. Barata, A. G. Fernandes, C. M. Correia, Univ. Coimbra (Portugal)

663019 Applications of rapid time-gated hyperspectral FLIM: live cell imaging of membrane order and 6-D microscopy [6630-44]

H. B. Manning, D. M. Owen, E. Auksorius, P. A. A. de Beule, S. Oddos, C. B. Talbot,

C. Dunsby, I. Munro, A. I. Magee, M. A. A. Neil, P. M. W. French, Imperial College London (United Kingdom)

6630 1A Fast three-dimensional random access multi-photon microscopy for functional recording of neuronal activity [6630-45]

D. Reddy, Rice Univ. (USA); P. Saggau, Baylor College of Medicine (USA) and Rice Univ. (USA)

6630 1C Multiphoton fluorescence lifetime imaging of Karpas 299 cells using ACT1 antibody conjugated gold nanoparticles [6630-47]

X. QU, Xi'an Jiaotong Univ. (China); K. Norbert, Univ. Lübeck (Germany); Z. Li, J. Wang,

Z. Zhang, Xi'an Jiaotong Univ. (China); G. Hüttmann, Univ. Lübeck (Germany)

Author Index 
Downloaded From: https://www.spiedigitallibrary.org/conference-proceedings-of-spie on 26 Apr 2023

Terms of Use: https://www.spiedigitallibrary.org/terms-of-use 


\title{
Conference Committee
}

\author{
General Chairs
}

David Boas, Massachusetts General Hospital (USA)

Stefan Andersson-Engels, Lunds Tekniska Högskola (Sweden)

Symposium Chairs

Wolfgang Drexler, Cardiff University (United Kingdom)

Mary-Ann Mycek, University of Michigan (USA) and University of Michigan Medical School (USA)

Conference Chairs

Tony Wilson, University of Oxford (United Kingdom)

Ammasi Periasamy, University of Virginia (USA)

Program Committee

Alberto Diaspro, Università degli Studi di Genova (Italy)

Daniel L. Farkas, Cedars-Sinai Medical Center (USA)

Hans C. Gerritsen, Universiteit Utrecht (Netherlands)

Enrico Gratton, Beckman Laser Institute and Medical Clinic (USA)

Stefan W. Hell, Deutsches Krebsforschungszentrum (Germany)

Karsten König, Fraunhofer-Institut für Biomedizinische Technik (Germany)

Jerome Mertz, Boston University (USA)

David W. Piston, Vanderbilt University (USA)

Peter T. C. So, Massachusetts Institute of Technology (USA)

Ernst H. K. Stelzer, European Molecular Biology Laboratory (Germany)

Sunny Xie, Harvard University (USA)

\section{Session Chairs}

1 Applications for Cellular and Tissue Imaging

Damian Bird, University of Melbourne (Australia)

2 Fluorescence Lifetime Imaging Microscopy

Ammasi Periasamy, University of Virginia (USA)

3 Accuracy and Quantitation in Microscopy

David W. Piston, Vanderbilt University (USA) 
$4 \quad$ Advanced Instrumentation for Microscopy I

Tony Wilson, University of Oxford (United Kingdom)

5 Advanced Instrumentation for Microscopy II

Chrysanthe Preza, University of Memphis (USA)

6 Microscopy in Dermatology

Peter T. C. So, Massachusetts Institute of Technology (USA)

Poster Session

Tony Wilson, University of Oxford (United Kingdom) 